\title{
Characterization and Corrosion Behavior of Plasma Sprayed Pure and Reinforced HA Coatings in Simulated Body Fluid
}

\author{
Gurbhinder Singh*, Surendra Singh and Satya Prakash
}

Metallurgical and Materials Engineering Department, Indian Institute of Technology, Roorkee 247667, India

* Corresponding Author: gurbhinder@yahoo.com

\begin{abstract}
To evaluate the corrosion behavior in simulated body fluid pure and $10 \mathrm{wt} \% 80 \mathrm{Al}_{2} \mathrm{O}_{3}-20 \mathrm{TiO}_{2}$ reinforced HA coatings were successfully deposited by atmospheric plasma spray technique on SS-304L substrate alloy. To eliminate non favorable phases on the as sprayed coatings the coatings were heat treated at $700^{\circ} \mathrm{C}$ and $800^{\circ} \mathrm{C}$ for post coating heat treatment technique. Both pure and reinforced as sprayed and post coating heat treated coatings were characterized by $X R D$ and SEM/EDAX analysis for surface characterization and further evaluated by electrochemical test for corrosion behavior in simulated body fluids.
\end{abstract}

Keywords: Hydroxyapatite, Corrosion, Reinforcement, Post Coating Heat Treatment

\section{INTRODUCTION}

Stainless steel $(18 \mathrm{Cr}-8 \mathrm{Ni})$ was the first metallic biomaterial used successfully as an implant in orthopedic surgery in 1926 [1-2]. In recent years surgical stainless steel grades have been very commonly used for bio implants due to their comparatively low cost, good corrosion resistance, easy hot and cold workability and good mechanical properties. These materials when compared to polymeric and ceramic materials possess more superior tensile strength, fatigue strength, and fracture toughness, which are the key properties required of structural materials [3]. In recent years coating of the ceramics material HA on conventionally used metallic implants has attracted the attention of researchers in the concerned field. By coating HA on metallic parts one can take advantages of both materials. Where metallic components will impart high mechanical properties 
to bio implant, the porous ceramics coating will enhance the cell growth on its surface for the easy fixation of the implant in human body environment. Deposition of HA on metallic substrates has been applied by a wide range of surface deposition techniques including plasma spraying, high-velocity oxy-fuel spraying (HVOF), pulsed laser ablation, ion-beam sputtering, electrophoretic deposition, radio frequency magnetron sputtering, sol-gel and conventional ceramic processes that involve pressing and sintering [4-8]. Among these techniques thermal spray techniques offer the most attractive prospect of economy and efficient deposition of HA.

Plasma spray is the only technique which is clinically used and recommended by the Food and Drug Administration (FDA), USA, due to its excellent coating properties as compared to other techniques [9]. Although plasma sprayed is the only process which is clinically used for the coating to be used for biomedical applications but it is reported in the previous literature [10-11] that during these processes due to rapid cooling of the coated substrate, from very high temperatures, crystalline HA is converted into tri and tetra calcium phosphates $(\alpha-\mathrm{TCP}, \beta-\mathrm{TCP}$ and TTCP) and oxy hydroxyapatite (o-HA) phases. These phases are generally amorphous in nature and prone to dissolve in the human blood plasma, which cause instability of bio implant and ultimately failures of implant after some time [12]. Post heat treatment is reported to be very beneficial to eliminate these amorphous phases formed during plasma sprayed coating process [13-16]. It is also reported that with the improvement of structural integrity post heat treatment plays important role to enhance mechanical properties of HA coating and in the promotion of cell proliferation and bio integration [17-18].

\section{MATERIALS AND METHOD}

Commercially available HA powder having high crystallinity and size in range of $100-180 \mu \mathrm{m}$ was used for pure HA coating. Volume mean diameter D [4, 3] of the powder was $150.12 \mu \mathrm{m}$. $\mathrm{Al}_{2} \mathrm{O}_{3}-\mathrm{TiO}_{2}$ (80Alumina-20Titania) having grain size $10-40 \mu \mathrm{m}$ was used as reinforcement. 10 $\mathrm{wt} \% \mathrm{Al}_{2} \mathrm{O}_{3}-\mathrm{TiO}_{2}$ was reinforced in pure $\mathrm{HA}$ by weight for reinforced coating as suggested by the previous literature $[11,17]$. Both pure and reinforced HA powders were deposited by atmospheric plasma spray process. All process parameters of plasma spray process were explained in the previous work [19, 20, 21]. From the SEM micrograph as shown in Fig. 1, it can be seen that both the HA and reinforced materials have angular crushed shape.

Coating of pure and reinforced HA was carried out by Plasma Spray System at Anod Plasma Spray Limited, Kanpur, India. Commercially available SS-304L alloy strip (ASTM A 240) having thickness $5 \mathrm{~cm}$ was used as a substrate material. Samples to be coated were grit blasted using alumina having size $60-80 \mu \mathrm{m}$ at blasting pressure $0.44 \mathrm{MPa}$ for good coating adhesion. Average value of surface roughness of the sample after the sand blasting was $7.30 \mu \mathrm{m}$. Parameters of coating are given below in Table I. 


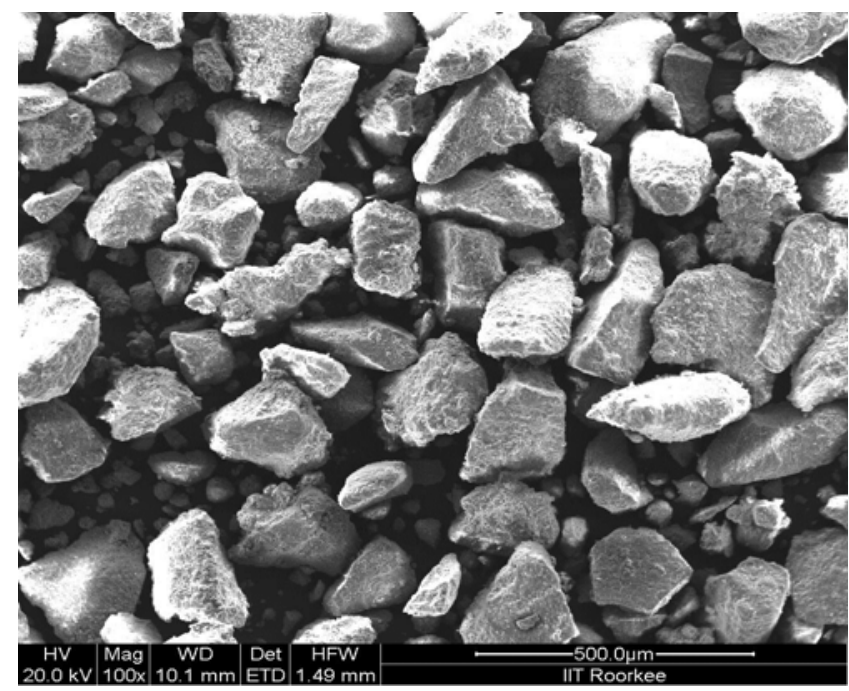

(a)

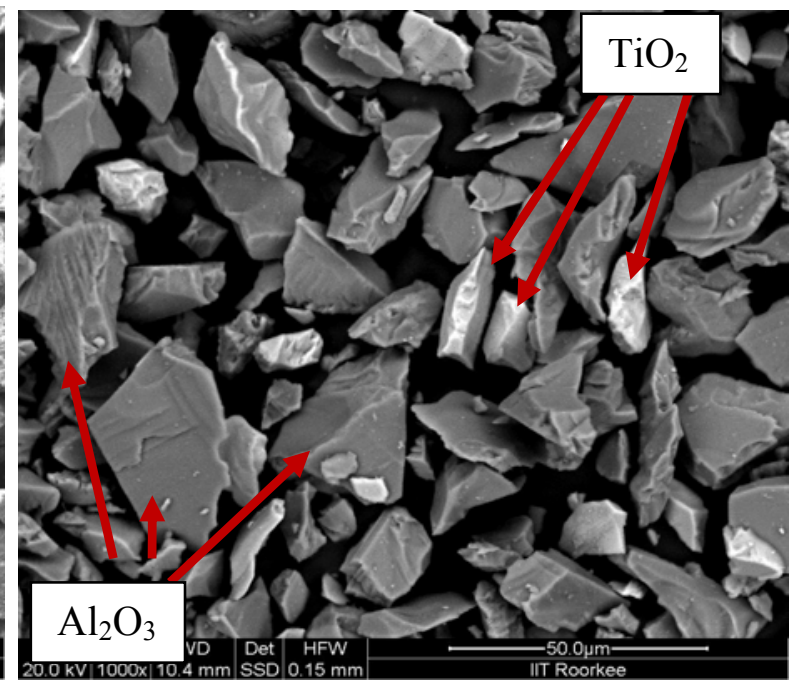

(b)

Fig .1 SEM micrograph of (a) pure HA and (b) $\left(80 \mathrm{Al}_{2} \mathrm{O}_{3}-20 \mathrm{TiO}_{2}\right)$

Table I. Spraying parameters of pure and reinforced HA coating

\begin{tabular}{|l|l|l|}
\hline S. No & Coating Parameter & Units \\
\hline 1 & Current (A): & 750 \\
\hline 2 & Voltage (V): & 50 \\
\hline 3 & Arc Pressure (PSI): & 60 \\
\hline 4 & Powder Pressure (PSI): & 80 \\
\hline 5 & Hopper RPM: & 5.4 \\
\hline 6 & Hydrogen Pressure (PSI): & 10 \\
\hline 7 & Stand of Distance (mm): & 105 \\
\hline 8 & Powder Rate g/min: & 35 \\
\hline 9 & Plasma Gun diameter (mm): & 7 \\
\hline
\end{tabular}

Post heat treatment of as sprayed coating has been carried out at a temperature of $700{ }^{\circ} \mathrm{C}$ and $800^{\circ} \mathrm{C}$ for two hours. The coated pieces were placed in the furnace as shown in the Fig. 2 and then the temperature was raised from room temperature to the desired temperatures i.e. $700{ }^{\circ} \mathrm{C}$ and $800{ }^{\circ} \mathrm{C}$ at the rate of nearly $5{ }^{\circ} \mathrm{C} / \mathrm{min}$. After attaining the desired temperature samples were heated for two hours. After two hours furnace power supply was stopped and the coated samples were left as such for 9-10 hrs for annealing.

$\mathrm{X}$ ray diffraction analysis (Bruker- Binary $\mathrm{V}_{3}$ ) was carried out to analyze the phase structure of as sprayed and post coating heat treated coated surfaces by taking radiation source $\mathrm{CuK}_{\alpha}$ at angle $10^{\circ}$ to $60^{\circ}$. There are many methods to determine the crystallinity of HA coatings using X-ray diffraction like Rutland Method, Relative Intensity Method and Rietveld Method. But in 
previous literature it is reported that Rutland Method is an accurate method for determining crystallinity $[17,18]$. In this method crystallinity is calculated by comparing the total area under the diffraction pattern with the area of the amorphous region of the pattern. The $\%$ crystallinity is determined by using equation as:

$$
\text { Crystallinity }(\%)=\frac{\sum \mathrm{A}_{\mathrm{c}}}{\sum \mathrm{A}_{\mathrm{c}}+\sum \mathrm{A}_{\mathrm{a}}} \times 100
$$

Where $\sum \mathrm{A}_{c}$ is the sum of the areas of all HA crystalline peaks and $\sum \mathrm{A}_{\mathrm{a}}$ is the sum of area under the amorphous peaks.

As sprayed pure and reinforced HA coatings and post coated heat treated coatings were tested for corrosion in simulated body fluid by electrochemical polarization test. SBF solution was prepared according to the composition suggested by Kokubo [22]. The ion concentration of SBF and human blood plasma are compared in Table II. The test was carried out on three electrode corrosion cell interfaced with a potentiostat of model (PARSTAT, Princeton Applied Research, USA) which consist of $\mathrm{Ag} / \mathrm{AgCl}$ as reference electrode and counter electrode. Sample which to be polarized acted as working electrode. The area of the sample exposed to SBF solution was $1 \mathrm{~cm}^{2}$. Samples were immersed in the SBF solution for $2 \mathrm{~h}$ before running the test. The corrosion current density values were calculated by Tafel slope methods which are shown in result section.

Table II. Ion concentrations of SBF and human blood plasma [22]

\begin{tabular}{|c|c|c|c|}
\hline S. No. & Ion & $\begin{array}{c}\text { Human Blood } \\
\text { Plasma }\end{array}$ & $\begin{array}{c}\text { Simulated Body } \\
\text { Fluid (SBF) }\end{array}$ \\
\hline 1 & $\mathrm{Na}^{+}$ & 142.0 & 142.0 \\
\hline 2 & $\mathrm{~K}^{+}$ & 5.0 & 5.0 \\
\hline 3 & $\mathrm{Mg}^{2+}$ & 1.5 & 1.5 \\
\hline 4 & $\mathrm{Ca}^{2+}$ & 2.5 & 2.5 \\
\hline 5 & $\mathrm{Cl}^{-}$ & 103.0 & 147.8 \\
\hline 6 & $\mathrm{HCO}^{3-}$ & 27.0 & 4.2 \\
\hline 7 & $\left(\mathrm{HPO}_{4}\right)^{2-}$ & 1.0 & 1.0 \\
\hline 8 & $\left(\mathrm{SO}^{2-}\right)^{2-}$ & 0.5 & 0.5 \\
\hline
\end{tabular}

\section{RESULTS \& DISCUSSION}

$\mathrm{XRD}$ analysis of pure and reinforced HA (as sprayed and post coating heat treated at $700^{\circ} \mathrm{C}$ and $800^{\circ} \mathrm{C}$ ) coatings are shown in Fig. 2 (a) and (b) respectively. It can be seen from the XRD 
analysis that in case of both as sprayed pure and reinforced coatings some amorphous phases are present which are completely eliminated in case of post coating heat treated coatings at $700^{\circ} \mathrm{C}$ and $800^{\circ} \mathrm{C}$. Similar phases were reported in previous literature $[10,12]$. Further it can be observed from the graph that HA peaks, which are present in as sprayed coatings in both cases (i.e. pure and reinforced HA coatings) become more crystalline when the coatings are treated at $700^{\circ} \mathrm{C}$ and $800^{\circ} \mathrm{C}$. Crystallinity and amorphous phases present in these coatings are present in the Table III. It can bee observed from the Table III that crystallinity of pure HA as sprayed and sintered coatings have slightly greater than reinforced HA as sprayed and sintered coatings. Non favorable phases which were present in the as sprayed coatings are completely removed by post coating heat treatment processes carried out $700^{\circ} \mathrm{C}$ and $800^{\circ} \mathrm{C}$. Similar observation has been reported by previous research work [13-16]. Non favorable phases, which are amorphous in nature, present in as sprayed pure and reinforced HA coatings can also be seen in Fig. 2(a) and 2(b) which are not present in pure and reinforced HA coatings sintered at $700^{\circ} \mathrm{C}$ and $800^{\circ} \mathrm{C}$. Magnifying view of these amorphous phases present in as sprayed pure and reinforced HA coatings can be seen in Fig. 2(a) and 2(b). Further it can be noticed that amorphous phases present in reinforced as sprayed HA coatings are slightly grater than pure as sprayed HA coatings this may be result of reaction of reinforcement contents with hydroxyapatite coating at higher temperature as suggested by previous literature [13,23].

Table III. Crystallinity and Non favorable phases present in as sprayed and heat treated pure and reinforced HA coatings

\begin{tabular}{|c|l|l|l|}
\hline S. No. & Coating & $\begin{array}{l}\text { Crystallinity } \\
(\mathbf{\%})\end{array}$ & $\begin{array}{l}\text { Non Favorable } \\
\text { phases (\%) }\end{array}$ \\
\hline 1 & $\begin{array}{l}\text { AS sprayed pure HA } \\
\text { coating }\end{array}$ & 68.2 & 12.34 \\
\hline 2 & $\begin{array}{l}\text { As sprayed reinforced } \\
\text { HA coatings }\end{array}$ & 66.8 & 14.45 \\
\hline 3 & $\begin{array}{l}\text { Pure HA coating } \\
\text { sintered at } 700^{\circ} \mathrm{C}\end{array}$ & 85.6 & Nil \\
\hline 4 & $\begin{array}{l}\text { Reinforced } \mathrm{HA} \mathrm{coating} \\
\text { sintered at } 700^{\circ} \mathrm{C}\end{array}$ & 84.5 & Nil \\
\hline 5 & $\begin{array}{l}\text { Pure } \mathrm{HA} \mathrm{coating} \\
\text { sintered at } 800^{\circ} \mathrm{C}\end{array}$ & 83.9 & Nil \\
\hline 6 & $\begin{array}{l}\text { Reinforced } \mathrm{HA} \text { coating } \\
\text { sintered at } 800^{\circ} \mathrm{C}\end{array}$ & 82.2 & Nil \\
\hline
\end{tabular}



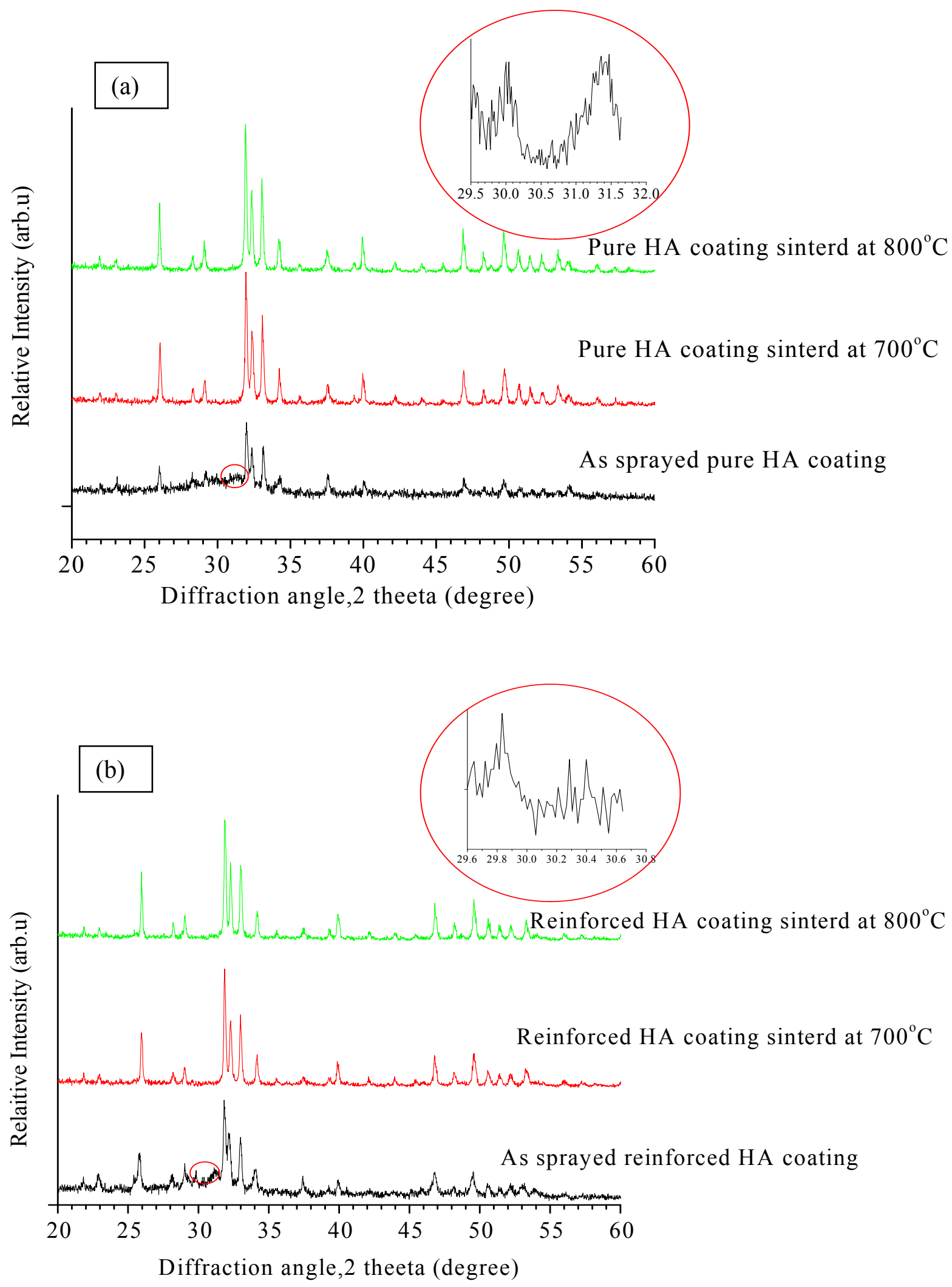

Fig. $2 \mathrm{XRD}$ analysis of the (a) pure HA as sprayed and sintered coatings, (b) reinforced HA as sprayed and sintered coatings 
Tafel polarization curves of pure and reinforced as sprayed and post coating heat treated coatings are presented in Fig. 3(a) and 3(b) respectively. The range of passivation potential for bare SS$304 \mathrm{~L}$ substrate, pure $\mathrm{HA}$ as sprayed coating, post coating heat treated at $700^{\circ} \mathrm{C}$ and $800^{\circ} \mathrm{C}$ are $660 \mathrm{mV}$ to $-160 \mathrm{mV},-650 \mathrm{mV}$ to $-150 \mathrm{mV},-700 \mathrm{mV}$ to $-200 \mathrm{mV}$ and $-380 \mathrm{mV}$ to $70 \mathrm{mV}$ respectively, whereas for reinforced as sprayed ,post coating heat treated at $700^{\circ} \mathrm{C}$ and $800^{\circ} \mathrm{C}$ coating it is $-700 \mathrm{mV}$ to $-200 \mathrm{mV},-520 \mathrm{mV}$ to $50 \mathrm{mV}$ and $-420 \mathrm{mV}$ to $20 \mathrm{mV}$ respectively. Results of polarization test are reported in Table IV. As it is evident from the Table IV that corrosion current is maximum in case of bare SS-304L substrate. So all pure and reinforced as sprayed as well as post coating heat treated coatings are protective in simulated body fluid solution. Pure HA coating has shown minimum corrosion resistance among the all HA coatings, where as with incorporation of reinforcement it has improved by $9 \%$. The coatings heat treated at $700^{\circ} \mathrm{C}$ and $800^{\circ} \mathrm{C}$ have shown superior corrosion resistance as compared to as sprayed coatings. The results are compatible with the work presented by the previous researches [24, 25]. Existing literature $[24,25]$ suggested the improvement of corrosion resistance may be due to improved crystallinity after post coating heat treatment process. However it can be also observed from the Table IV that heat treated coatings at $800^{\circ} \mathrm{C}$ have shown comparatively poor corrosion resistance as compared to the coatings heat treated at $700^{\circ} \mathrm{C}$.

Table IV Result of Tafel polarization test

\begin{tabular}{|l|l|l|l|l|}
\hline \multicolumn{1}{|c|}{ Specimen } & \multicolumn{1}{|c|}{$\begin{array}{c}\text { E Corr. } \\
(\mathbf{m v})\end{array}$} & $\begin{array}{c}\text { I Corr. } \\
(\boldsymbol{\mu A})\end{array}$ & \multicolumn{1}{|c|}{$\begin{array}{c}\boldsymbol{\beta a} \\
(\mathbf{m v})\end{array}$} & \multicolumn{1}{|c|}{$\begin{array}{c}\boldsymbol{\beta c} \\
(\mathbf{m v})\end{array}$} \\
\hline Bare substrate alloy (SS-304L) & -408.216 & 2.743 & 385.532 & 296.380 \\
\hline Pure HA as sprayed coating & -485.586 & 1.60 & 123.769 & 49.515 \\
\hline Pure HA coating sintered at $700^{\circ} \mathrm{C}$ & -520.504 & 0.737 & 74.467 & 44.570 \\
\hline Pure HA coating sintered at $800^{\circ} \mathrm{C}$ & -199.032 & 0.979 & 118.853 & 66.326 \\
\hline Reinforced HA as sprayed Coating & -497.876 & 1.46 & 102.266 & 40.860 \\
\hline Reinforced HA coating sintered at $700^{\circ} \mathrm{C}$ & -250.733 & 0.468 & 165.103 & 93.940 \\
\hline Reinforced HA coating sintered at $800^{\circ} \mathrm{C}$ & -309.812 & 0.649 & 169.592 & 105.626 \\
\hline
\end{tabular}



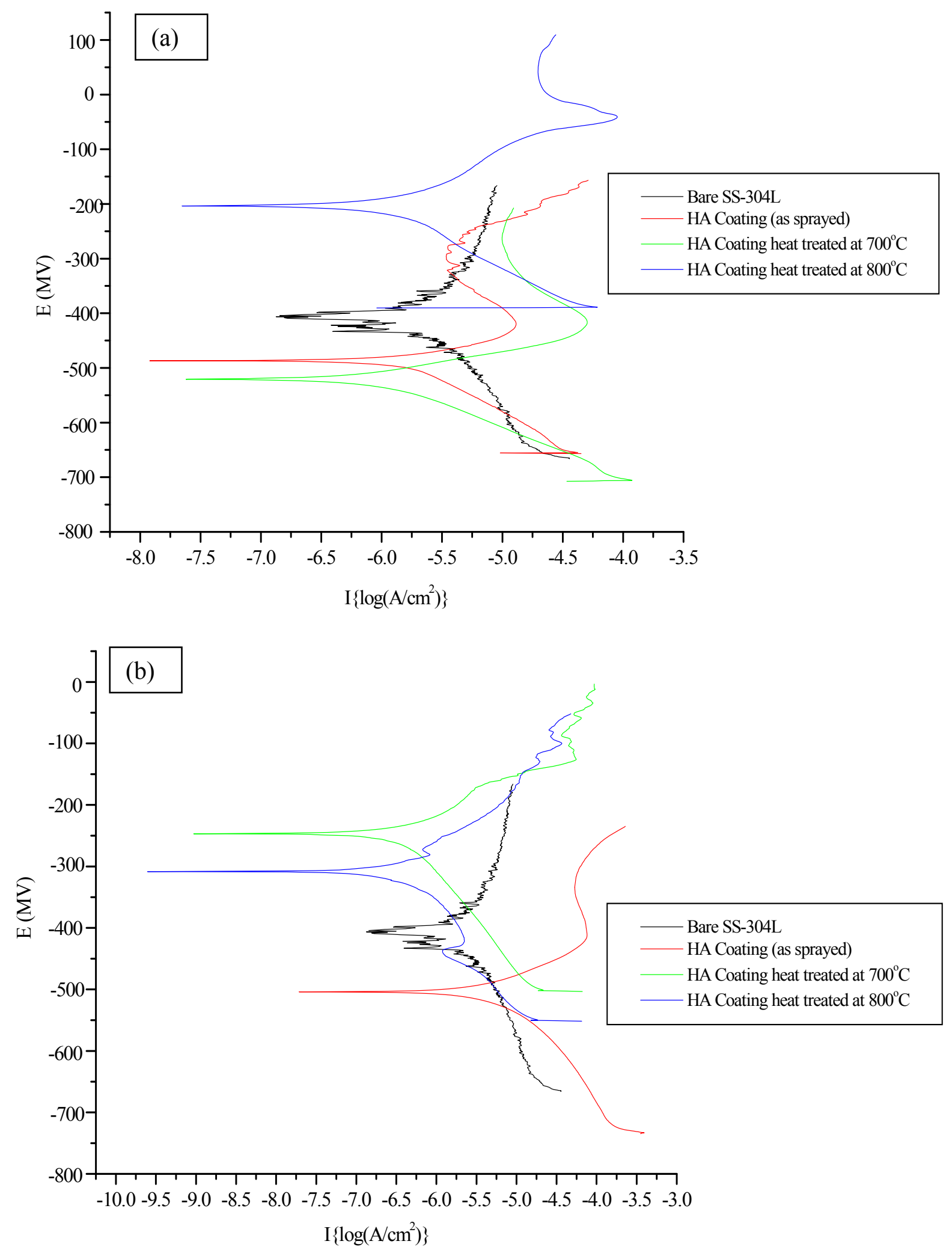

Fig. 3 Tafel polarization curves for (a) bare ss-304L, pure HA as sprayed and sintered coating at $700^{\circ} \mathrm{C}$ and $800^{\circ} \mathrm{C}$, (b) reinforced as sprayed and sintered coating at $700^{\circ} \mathrm{C}$ and $800^{\circ} \mathrm{C}$ 


\section{CONCLUSIONS}

Pure and $10 \%$ wt $\left(80 \mathrm{Al}_{2} \mathrm{O}_{3}-20 \mathrm{TiO}_{2}\right)$ reinforced hydroxyapatite coating was successfully deposited on SS-304L substrate by plasma sprayed process. Both coatings were sintered at $700^{\circ} \mathrm{C}$ and $800^{\circ} \mathrm{C}$. All these coatings were characterized by xrd analysis to evaluate amorphous phases and crystallinity of the coatings. Theses coatings were also tested for corrosion in simulated body fluids. Following conclusions can be drawn from the xrd characterization and corrosion behavior of in SBF.

1. Some non amorphous phases were detected in case of both as sprayed pure and reinforced HA coatings, which were completely eliminated by post coating heat treatment of the coatings at $700^{\circ} \mathrm{C}$ and $800^{\circ} \mathrm{C}$.

2. Crystallinity of the both as sprayed pure and reinforced HA coatings was improved by post coating heat treatment process.

3. Reinforced HA as sprayed coating has shown slightly larger amorphous phase as compared to pure HA as sprayed coating.

4. All coatings (i.e. as sprayed and heat treated) have shown superior corrosion resistance as compared to bare SS-304L alloy. However all as sprayed HA coatings have shown poor corrosion resistance as compared to all HA heat treated HA coatings.

\section{REFERENCES}

1. C.N. Elias, J.H.C. Lima, R. Valiev, and M.A. Meyers, 2008 "Biomedical Applications of Titanium and its Alloys", Journal of the Minerals, Metals and Materials Society, Vol. 60, No. 3, pp. 46-49.

2. David F. Williams, 1981, Biocompatibility of Clinical Implant Materials, 1st ed., CRC Press.

3. M. Younesi, M.E. Bahrololoom, M. Ahmadzadeh, 2010, "Prediction of wear behaviors of nickel free stainless steel-hydroxyapatite bio-composites using artificial neural network", Computational Materials Science, Vol. 47, pp. 645-654.

4. Y.C. Tsui, C. Doyle, T.W. Clyne, 1998, "Plasma sprayed hydroxyapatite coatings on titanium substrates Part 1: Mechanical properties and residual stress levels", Biomaterials Vol. 19, pp. 2015-2029.

5. C. Garcia, S. Cere, A. Dura, 2004, "Bioactive coatings prepared by sol-gel on stainless steel 316L”, J. Non-Cryst. Solids, Vol. 348, pp. 218-224.

6. Xin Pang, Igor Zhitomirsky, 2007, "Electrophoretic deposition of composite hydroxyapatite-chitosan coatings", Mater. Charac. Vol. 58, pp. 339-348.

7. W.U. Zhen-Jun, H.E.Li-ping, Chen Zong-Zhang, 2006, "Fabrication and characterization of hydroxyapatite $/ \mathrm{Al}_{2} \mathrm{O}_{3}$ bio-composite coating on titanium, Trans. Nonferrous Met. SOC. China, Vol. 16, pp. 259-266. 
8. M.H. Fathi, F. Azam, 2007, "Novel hydroxyapatite/tantalum surface coating for metallic dental implant", Mater. Lett. Vol. 61, pp. 1238-1241.

9. Kantesh Balani, Yao Chen, Sandip P. Harimkar, Narendra B. Dahotre, Arvind Agarwal, 2007, "Tribological behavior of plasma-sprayed carbon nanotube-reinforced hydroxyapatite coating in physiological solution", Acta Biomaterialia , Vol. 3, pp. 944951.

10. M.F. Morks and Akira Kobayashi, 2007 "Effect of gun current on the microstructure and crystallinity of plasma sprayed Hydroxyapatite coating”, Applied Surface Science, Vol. 253, pp. 7136-7142.

11. M.F. Morks, N.F. Fahim and A. Kobayashi,2008, "Structure, mechanical performance and electrochemical characterization of plasma sprayed $\mathrm{SiO}_{2} /$ Ti-reinforced hydroxyapatite biomedical coatings", Applied Surface Science, Vol. 255, Part 2, pp. 3426-3433.

12. Wenxiu Que, K.A. Khor, J.L. Xu, L.G. Yu, 2008, "Hydroxyapatite/titania nanocomposites derived by combining high-energy ball milling with spark plasma sintering processes", Journal of the European Ceramic Society, Vol. 28, pp. 3083-3090.

13. Huaxia Ji, P.M.Marquis, 1993, "Effect of heat treatment on the microstructure of plasmasprayed hydroxyapatite coating" Biomaterials, Vol. 14,No. 1,pp.64-68.

14. Yu Peng Lu, Yi Zhong Song, Rui Fu Zhu, Mu Sen Li, Ting Quan Lei, 2003, “ Factors influencing phase compositions and structure of plasma sprayed hydroxyapatite coatings during heat treatment" Applied Surface Science,Vol.206, pp. 345-354.

15. Shinn-jyh Ding, Tsui-hsien Huang, Chia-tze Kao, 2002, "Immersion behavior of plasma sprayed modified hydroxyapatite coatings after heat treatment", Surface and Coatings Technology, Vol. 165, pp. 248-257.

16. Zhao Guo-liang, Wen Guang-wu, Wu Kun, 2009, "Influence of processing parameters and heat treatment on phase composition and microstructure of plasma sprayed hydroxyapatite coatings", Trans. Nonferrous Met. Soc. China, vol.19, pp. 463- 469.

17. Bang Yen Chou, Edward Chang, 1999, "Microstructural characterization of plasma sprayed hydroxyapatite $10 \mathrm{wt} \% \mathrm{ZrO}_{2}$ composite coating on titanium”, Biomaterials, Vol. 20, pp. 1823-1832.

18. Y.C. Tsui, C. Doyle and T.W. Clyne, 1998, "Plasma sprayed hydroxyapatite coatings on titanium substrates Part 2: optimization of coating properties”, Biomaterials 1998, 19, p 2031-2043.

19. Singh Gurbhinder, Singh Surendra, Prakash Satya, (2011), "Surface characterization of plasma sprayed pure and reinforced hydroxyapatite coating on Ti6Al4V alloy", Surface and Coatings Technology, Vol. 205, pp. 4814-4820.

20. Singh Gurbhinder, Singh Surendra, Prakash Satya, (2011), "Post Heat Treatment of Plasma Sprayed Pure and Alumina-Titania Reinforced Hydroxyapatite Coating on SS 304 Steel", Journal of Minerals \& Materials Characterization \& Engineering, Vol. 10, No.2, pp.173-184. 
21. Singh Gurbhinder, Singh Surendra, Prakash Satya, (2010), "Role of Post Heat Treatment of Plasma Sprayed Pure and $\mathrm{Al}_{2} \mathrm{O}_{3}-\mathrm{TiO}_{2}$ Reinforced Hydroxyapatite Coating on the Microstructure and Mechanical Properties", published in Journal of Minerals \& Materials Characterization \& Engineering, Vol. 9, No.12, pp.1059-1069.

22. Tadashi Kokubo, 1990 "Surface chemistry of bioactive glass-ceramics" Journal of NonCrystalline Solids, Vol. 120, pp.138-151.

23. B. Viswanath, N. Ravishankar, 2006, "Interfacial reactions in hydroxyapatite/alumina nano-composites", Scripta Materialia, Vol. 55, pp. 863-866.

24. Lee Yi-Pang, Wang Chih-Kuang, Huang Tsui-Hsien, Chen Chun-Cheng, Kao Chia-Tze, Ding Shinn-Jyh, 2005, "In vitro characterization of post heat-treated plasma-sprayed hydroxyapatite coatings", Surface \& Coatings Technology, Vol. 197, pp. 367- 374.

25. Chen C.C., Huang T.H., Kao C.T., Ding S.J., 2004, "Electrochemical study of the in vitro degradation of plasma-sprayed hydroxyapatite/bioactive glass composite coatings after heat treatment”, Electrochimica Acta, Vol. 50, pp. 1023-1029. 